\title{
Distal Bile Duct Cancer pM1 TNM Finding v8
}

National Cancer Institute

\section{Source}

National Cancer Institute. Distal Bile Duct Cancer pM1 TNM Finding v8. NCI Thesaurus.

Code C134796.

Distal bile duct cancer with distant metastasis. (from AJCC 8th Ed.) 